\title{
EFEKTIVITAS INTERVENSI MEDIA POSTER TERHADAP PENGETAHUAN, SIKAP, DAN PERILAKU MASYARAKAT MENGENAI TUBERKULOSIS DI KECAMATAN CIMERAK, PANGANDARAN, JAWA BARAT
}

\author{
Heda Melinda N. Nataprawira, dan I Wayan Andrew Handisurya \\ Departemen/Kelompok Staf Medis Ilmu Kesehatan Anak, Fakultas Kedokteran Universitas Padjadjaran/Rumah \\ Sakit Umum Pusat Hasan Sadikin \\ E-mail: heda_1155@yahoo.com
}

\begin{abstract}
ABSTRAK. Masalah tuberkulosis (TB) masih tetap merupakan tantangan Indonesia hingga saat ini. Badan Kesehatan Dunia melaporkan Indonesia berada di peringkat ketiga negara dengan beban TB tertinggi di dunia. Untuk mencapai target eliminasi TB pada tahun 2050 maka seluruh komponen masyarakat harus ikut berperan dalam menghadapi permasalahan global TB. Sebagai implementasinya maka Universitas Padjadjaran (Unpad) dalam mendukung kegiatan Tri Dharma perguruan tinggi melaksanakan kegiatan Supercamp. Penelitian potong lintang mengenai pengetahuan, sikap, dan perilaku dilakukan pada masyarakat di Kecamatan Cimerak sebagai bagian dari kegiatan Supercamp 2016 untuk mengetahui karakteristik dasar masyarakat terhadap penyakit TB. Pengisian kuesioner terkait pengetahuan, sikap, dan perilaku dilakukan sebelum dan sesudah penjelasan dengan menggunakan media poster mengenai TB pada Agustus 2016. Dengan menggunakan metode stratified random sampling didapatkan 156 responden dari 11 desa. Hasil survei menunjukkan peningkatan pengetahuan masyarakat terhadap penyakit TB yang signifikan setelah sosialisasi dalam hal tanda dan gejala penyakit $(p 0,03)$, cara penularan $(p 0,01)$ dan cara pencegahan penularan $(p 0,001)$. Sikap negatif masih tampak dengan memberikan stigmatisasi terhadap penderita TB $(26,7 \%)$. Mayoritas subjek akan pergi ke fasilitas kesehatan apabila terkena TB $(84,1 \%)$ namun masih ada subjek yang memilih untuk mengobati sendiri (2,5\%) ataupun berobat alternatif (1,3\%). Pemaparan materi mengenai TB memberikan perubahan yang diharapkan dapat membantu mengurangi beban penyakit TB di dalam komunitas endemik TB dengan memodifikasi sikap, dan perilaku.
\end{abstract}

Kata kunci: pengetahuan, sikap, perilaku, tuberkulosis, Supercamp

\begin{abstract}
Tuberculosis (TB) problem is still a challenge in Indonesia. World Health Organization reported that Indonesia is ranked third in countries with the highest burden of disease in TB. To achieve the target of TB elimination in the year 2050, the whole community components have to participate in facing global TB problem. As its implementation, Padjadjaran University (Unpad), in support of the Tri Dharma principle, does a yearly Supercamp event. A cross-sectional questionnaire about knowledge, attitude and practice was conducted in the sub-district of Cimerak as part of 2016 Supercamp event to find out community's baseline characteristics against tuberculosis (TB). The survey was done before and after socialization using poster media about TB in August 2016. By using stratified random sampling method we obtained 156 respondents from 11 villages. The results of the survey showed significant changes in knowledge after socialization in terms of signs and symptoms of disease ( $p 0.03)$, mode of transmission ( $p 0.01)$ and prevention mode of transmission (p-value 0.001). Negative attitude is still evident by giving stigmatization to TB patient (26.7\%). The majority of subjects will go to health facilities for TB treatment (84.1\%) but there are still subjects who choose to seek self-treatment (2.5\%) or alternative treatment $(3 \%)$. Presentation of TB made several changes in community knowledge that may help in reducing the burden of TB disease in TB endemic communities by modifying their attitude and practice.
\end{abstract}

Key words: knowledge, attitude, practice, tuberculosis, Supercamp

\section{PENDAHULUAN}

Sedikitnya sepertiga populasi dunia menderita infeksi tuberkulosis (TB) dan sebanyak 8,8 juta penduduk dunia menderita penyakit TB setiap tahunnya. Indonesia merupakan salah satu negara di dunia dengan beban penyakit TB tertinggi di dunia. Beban penyakit TB yang besar ini berkaitan dengan beban ekonomi yang akan dikeluarkan dalam hal biaya pelayanan medis, biaya pelayanan nonmedis yang dikeluarkan oleh pasien TB, hilangnya produktivitas akibat disabilitas karena penyakit TB dan serta kehilangan produktivitas karena kematian. Masalah TB masih tetap merupakan tantangan Indonesia hingga saat ini. Badan Kesehatan Dunia melaporkan Indonesia berada di peringkat ketiga negara dengan beban TB tertinggi di dunia. Penyakit TB disebabkan oleh kuman Mycobacterium tuberculosis. Penyebaran penyakit ini melalui kuman yang disebarkan di udara oleh orang yang sakit TB kepada orang sehat. Meskipun pengobatan TB selama 6 bulan dilakukan cukup efektif, namun tantangan terbesar dalam tata laksana TB adalah kurangnya kepatuhan terhadap pengobatan TB.

Beberapa faktor yang berkaitan dengan ketidak patuhan pengobatan TB adalah kemiskinan, koinfeksi HIV, jenis kelamin laki-laki, pengetahuan dan kepedulian terhadap penyakitnya. Tingkat sosioekonomi dan pendidikan yang rendah ini berkaitan dengan pengetahuan, sikap, dan perilaku terhadap TB yang salah, sehingga penyebaran TB tidak dapat dicegah, serta pengobatan TB tidak dilaksanakan dengan baik dan benar.

Penelitian yang dilakukan di beberapa negara seperti Pakistan, Thailand, dan Indonesia mengenai hubungan sosiokultural dengan penyakit TB menunjukkan bahwa sebagian besar penderita TB adalah masyarakat miskin yang tidak mengerti mengenai penyakit TB, sehingga masyarakat tidak menyadari bahwa dirinya 
dapat menularkan penyakit TB, tidak melakukan upaya pencegahan penularan $\mathrm{TB}$, dan tidak mau secara rutin pergi berobat ke fasilitas pelayanan kesehatan untuk mengambil obat TB. Oleh karena itu, tingkat pengetahuan, sikap, dan perilaku masyarakat terhadap penyakit TB sangatlah penting diketahui untuk menyusun strategi intervensi yang tepat.

Salah satu cara untuk mengetahui tingkat pengetahuan, sikap, dan perilaku tersebut adalah dengan survei knowledge, attitude and practice (KAP). Survei KAP adalah studi yang mewakili populasi tertentu untuk mengumpulkan informasi tentang apa yang diketahui, diyakini, dan dilakukan dalam kaitannya dengan topik tertentu. Survei KAP dapat mengidentifikasi kesenjangan pengetahuan, keyakinan budaya atau pola perilaku yang dapat memfasilitasi pemahaman dan tindakan, serta menimbulkan masalah atau menciptakan hambatan dalam upaya pengendalian TB. Saat ini penelitian mengenai hubungan KAP dengan TB di Indonesia masih terbatas dan belum banyak diteliti.

Sebagai salah satu upaya berpartisipasi dalam akselerasi pembangunan bidang kesehatan lokal yang selaras dengan agenda Sustainable Development Goals (SDG), Universitas Padjadjaran melakukan kegiatan pengabdian masyarakat di daerah binaan di Jawa Barat bagian selatan, yaitu kecamatan Cimerak, Pangandaran dalam kegiatan Supercamp. Masih rendahnya kesadaran akan pentingnya menjaga kebersihan dan kesehatan menyebabkan masyarakatnya rentan terserang penyakit seperti $\mathrm{TB}$. Oleh sebab itu, masalah kesehatan dan kebesihan merupakan prioritas utama dari pemerintah daerah setempat.

Salah satu kegiatan yang terintegrasi di dalam Supercamp adalah proyek penelitian yang mencakup berbagai disiplin ilmu yang bertujuan menerapkan Tri Darma Perguruan Tinggi mengenai pendidikan, penelitian, serta pengabdian. Survei KAP masyarakat Cimerak mengenai TB dilakukan untuk mengetahui karakteristik dasar/ baseline serta hubungan pengetahuan, sikap, dan perilaku masyarakat terhadap penyakit TB. Survei dilaku-kan dengan cara pengisian kuesioner. Pengisian kuesioner dilakukan dua kali yaitu sebelum dan sesudah pemaparan mengenai penyakit TB dengan media poster. Di antara pengisian kuesioner akan dilakukan sosialisasi TB melalui media poster TB sehingga diharapkan penelitian ini akan memberikan manfaat secara langsung kepada masyarakat berupa tambahan pengetahuan mengenai TB baik cara penularan, pencegahan, maupun pengobatan TB. Manfaat tidak langsung adalah hasil laporan akhir penelitian ini akan menjadi modal data yang berharga dalam penyusunan strategi penanggulangan TB di desa tersebut.

\section{METODE}

Metode yang digunakan adalah cross sectional dengan menggunakan kuesioner mengenai pengetahun, sikap, dan perilaku (knowledge, attitude and practice atau KAP) penyakit TB pada masyarakat. Kuesioner yang digunakan merupakan kuesioner KAP standar World Health Organization (modifikasi) yang bertujuan menjadi representatif populasi spesifik akan apa yang diketahui, dipercaya, dan dilakukan mengenai topik tertentu.

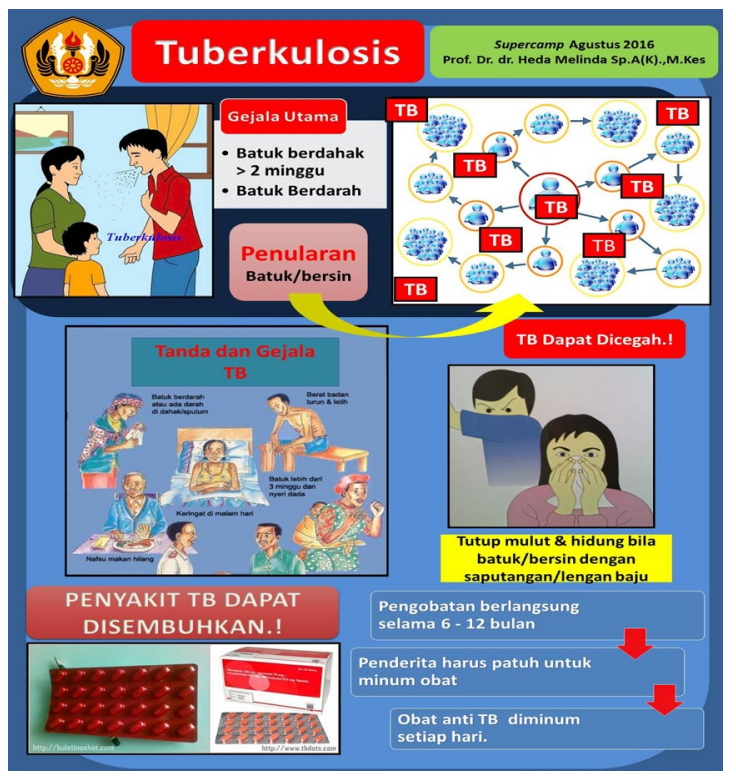

Gambar 1. Media Poster

Intervensi yang dilakukan adalah pemaparan media poster mengenai TB yang dilakukan di antara pengisian kuesioner. Media poster disusun berdasarkan panduan TB dari WHO dan Departemen Kesehatan. Pewawancara sebelumnya diberikan pelatihan singkat mengenai cara pengisian kuesioner dan sosialisasi media poster oleh peneliti.

Penelitian ini merupakan bagian dari kegiatan Supercamp 2016 yang dilakukan Universitas Padjajaran di 11 desa pada Kecamatan Cimerak, Kabupaten Pangandaran pada 13 Agustus 2016. Subjek penelitian ini adalah masyarakat di Kecamatan Cimerak yang diperoleh melalui stratified random sampling. Kriteria inklusi adalah bapak/ ibu yang berdomisili di Kecamatan Cimerak dengan alamat sesuai dengan Kartu Tanda Penduduk (KTP) di kecamatan tersebut, berusia di atas 18 tahun, dapat membaca dan menulis. Kriteria eksklusi adalah tidak berada di tempat pada saat visitasi langsung.

Pada penelitian ini, penentuan besarnya sampel ditentukan dengan menggunakan rumus, dengan Confdence Level ditentukan berdasarkan tabel z-score. Berdasarkan data kependudukan, jumlah penduduk (populasi) Kecamatan Cimerak, Kabupaten Pangandaran sebanyak 3.865 orang, dengan asumsi satu keluarga terdiri dari 5 orang maka jumlah kepala keluarga di Kecamatan Cimerak adalah 773 kepala keluarga dengan menggunakan rumus diperoleh besarnya sampel di desa Cimerak adalah sebanyak 156 orang dengan ketentuan margin of error: $+/-5 \%$, Confidence level: $90 \%$ dan standar deviasi: $30 \%$.

Pewawancara kemudian melakukan dengan cara kunjungan rumah menggunakan convenience sampling. Waktu yang diperlukan untuk mengikuti penelitian ini adalah 1 jam terdiri dari pengisian kuesioner pretest 15-20 


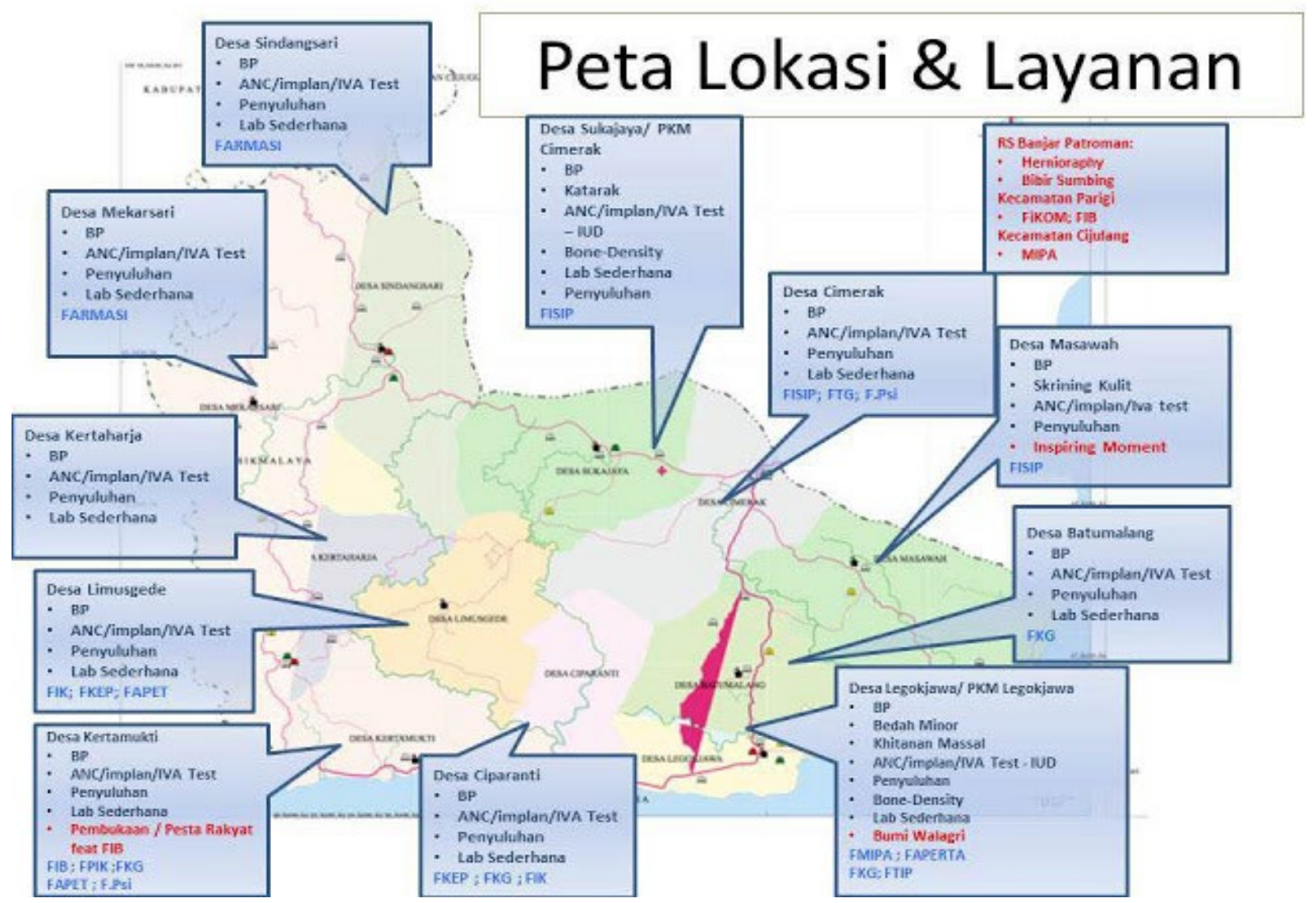

Gambar 2. Peta Lokasi Supercamp 2016 di Kecamatan Cimerak, Kabupaten Pangandaran

menit, pemaparan materi poster 20 menit dan pengisian kuesioner post-test 15-20 menit.

Data kemudian dimasukkan ke dalam spreadsheet Microsoft Excel, dan dianalisis menggunakan IBM SPSS 20. Pengetahuan dibandingkan antara pretest dan posttest menggunakan uji t-berpasangan. Sikap, dan perilaku kemudian dianalisis secara deskriptif untuk melihat gambaran karakteristik masyarakat.

Penelitian ini tidak membahayakan karena dilakukan hanya dengan mengisi kuesioner. Sebelum mengisi kuesioner, subjek penelitian menandatangani formulir persetujuan. Nama tidak ditulis dalam kuesioner sehingga kerahasiaan subjek penelitian terjamin.

\section{HASIL DAN PEMBAHASAN}

Pada Tabel 1, tampak mayoritas subjek adalah perempuan $(65 \%)$, berusia $>40$ tahun $(51,6 \%)$, pendidikan terakhir SD (43\%) dan telah bekerja $(73,4 \%)$. Mayoritas responden menyatakan bahwa jarak dari domisili ke fasilitas kesehatan tergolong dekat, yaitu $0-10 \mathrm{~km}$ $(94,9 \%)$. Wawancara dilakukan saat pagi hingga siang hari sehingga kebanyakan responden yang dapat ditemui berada di rumah adalah ibu rumah tangga. Mayoritas pekerjaan penduduk di Kecamatan Cimerak adalah petani sehingga pada saat wawancara dilakukan tidak berada di tempat karena sedang bekerja. Mayoritas subjek mengetahui fasilitas kesehatan terdekat, namun perlu diteliti lebih lanjut bagaimana masyarakat dan fasilitas kesehatan berperan dalam rangka mengurangi transmisi TB setempat.

Tabel 1. Demografis Subjek

\begin{tabular}{ll}
\hline Variabel & $\mathrm{N}(\%)$ \\
\hline Jenis kelamin & \\
Laki-laki & $53(33,5 \%)$ \\
Perempuan & $103(65,2 \%)$ \\
Usia & \\
18-20 tahun & $4(2,5 \%)$ \\
20-30 tahun & $29(18,5 \%)$ \\
31-40 tahun & $41(26,1 \%)$ \\
>40 tahun & $81(51,6 \%)$ \\
Pendidikan terakhir & \\
SD & $68(43 \%)$ \\
SMP & $37(23,4 \%)$ \\
SMA & $26(16,5 \%)$ \\
Sarjana & $22(13,9 \%)$ \\
Magister & $2(1,3 \%)$ \\
Jarak ke fasilitas kesehatan & \\
$0-10 \mathrm{~km}$ & $149(94,9 \%)$ \\
10-20 km & $4(2,5 \%)$ \\
20-30 km & $2(1,3 \%)$ \\
\hline
\end{tabular}

Survei sebelum dilakukan pemaparan mengenai penyakit TB, menunjukkan hasil bahwa data dasar/ baseline menenai tingkat pengetahuan, sikap, dan perilaku masyarakat terhadap penyakit TB masih rendah. Tingkat pengetahuan dilihat dari berapa banyak responden yang menjawab benar mengenai pertanyaan akan TB, baik berupa tanda dan gejala, cara penularan, cara pencegahan dan pengobatan TB.

Setelah dilakukan pemaparan mengenai penyakit TB dengan menggunakan media poster, didapatkan 
hasil yang berbeda. Hasil survei menunjukkan peningkatan tingkat pengetahuan masyarakat terhadap penyakit TB yang signifikan dalam hal tanda dan gejala penyakit $(p 0,03)$, cara penularan $(p 0,01)$, dan cara pencegahan penularan $(p 0,001)$. Tingkat pengetahuan setelah dilakukan pemaparan menunjukkan hasil yang lebih baik dibanding dengan sebelumnya, akan tetapi masih banyak responden yang tidak mengetahui TB bahkan setelah dilakukan pemaparan.

Tabel 2. Pengetahuan Subjek Mengenai TB

\begin{tabular}{|c|c|c|c|}
\hline Variabel & $\begin{array}{l}\text { Pre Test } \\
\text { N }(\%)\end{array}$ & $\begin{array}{l}\text { Post Test } \\
\text { N }(\%)\end{array}$ & $p$-value \\
\hline Tanda dan Gejala & & & 0,03 \\
\hline Ruam & $4(2,5)$ & $5(3,2)$ & \\
\hline Batuk & $72(45,8)$ & $99(63)$ & \\
\hline Batuk $>3$ minggu & $36(22,9)$ & $99(63)$ & \\
\hline Batuk berdarah & $53(33,8)$ & $114(72,6)$ & \\
\hline Sakit kepala berat & $11(7)$ & $11(7)$ & \\
\hline Mual & $9(5,7)$ & $15(9,6)$ & \\
\hline Penurunan berat badan & $31(19,7)$ & $76(48,4)$ & \\
\hline Demam & $23(14,6)$ & $26(16,6)$ & \\
\hline $\begin{array}{l}\text { Demam tanpa sebab jelas } \\
\text { lebih dari } 1 \text { minggu }\end{array}$ & $5(3,1)$ & $16(10,2)$ & \\
\hline Nyeri dada & $33(21)$ & $73(46,5)$ & \\
\hline Sesak napas & $44(28)$ & $55(35,7)$ & \\
\hline Lemah berkepanjangan & $13(8,2)$ & $14(8,9)$ & \\
\hline Cara penularan TB & & & 0,01 \\
\hline Melalui jabat tangan & $14(8,9)$ & $39(24,8)$ & \\
\hline $\begin{array}{l}\text { Melalui udara ketika } \\
\text { seseorang batuk/bersin }\end{array}$ & $78(49,7)$ & $138(87,9)$ & \\
\hline Melalui makanan & $37(23,6)$ & $28(17,8)$ & \\
\hline $\begin{array}{l}\text { Melalui alat makan yang } \\
\text { dipakai bersama }\end{array}$ & $54(34,4)$ & $44(28)$ & \\
\hline $\begin{array}{l}\text { Melalui sentuhan di tempat } \\
\text { umum (pintu, tempat } \\
\text { duduk) }\end{array}$ & $9(5,7)$ & $19(12,1)$ & \\
\hline $\begin{array}{l}\text { Cara pencegahan } \\
\text { penularan }\end{array}$ & & & 0,001 \\
\hline Menghindari jabat tangan & $16(10,2)$ & $17(10,8)$ & \\
\hline $\begin{array}{l}\text { Menutup mulut dan hidung } \\
\text { ketika batuk/bersin }\end{array}$ & $50(31,8)$ & $131(18,4)$ & \\
\hline $\begin{array}{l}\text { Menghindari berbagi } \\
\text { makanan }\end{array}$ & $20(12,7)$ & $18(11,5)$ & \\
\hline $\begin{array}{l}\text { Mencuci tangan ketika } \\
\text { sudah menyentuh benda di } \\
\text { tempat umum }\end{array}$ & $25(15,9)$ & $34(21,7)$ & \\
\hline Menutup jendela rumah & $7(4,5)$ & $7(4,5)$ & \\
\hline $\begin{array}{l}\text { Makan yang baik dan } \\
\text { teratur }\end{array}$ & $25(15,9)$ & $30(19,1)$ & \\
\hline Dengan berdoa & $12(7,6)$ & $13(8,3)$ & \\
\hline Pengobatan TB & & & 0,159 \\
\hline TB dapat disembuhkan & $123(78,3)$ & $144(91,7)$ & \\
\hline Pengobatan herbal & $24(15,3)$ & $13(8,3)$ & \\
\hline $\begin{array}{l}\text { Istirahat di rumah tanpa } \\
\text { berobat }\end{array}$ & $4(2,5)$ & $1(0,6)$ & \\
\hline Berdoa & $5(3,2)$ & $5(3,2)$ & \\
\hline $\begin{array}{l}\text { Obat-obatan spesifik dari } \\
\text { pusat pelayanan kesehatan }\end{array}$ & $93(59,2)$ & $95(60,5)$ & \\
\hline DOTS & $10(6,4)$ & $62(39,5)$ & \\
\hline
\end{tabular}

Tabel 3 memaparkan mengenai sikap subjek terhadap TB. Opini atau sikap masyaraka terhadap suatu penyakit sering kali dapat digunakan untuk menggambarkan pengetahuan akan penyakit tersebut. Mayoritas subjek mengerti bahwa TB adalah penyakit yang sangat berat $(74,5 \%)$ dan merasa takut apabila terdiagnosis TB $(48,4 \%)$ akan tetapi sikap negatif masih tampak dengan memberikan perlakuan yang negatif terhadap penderita TB (26,7\%). Stigmatisasi yang melekat pada penyakit dan penderita TB dapat menyebabkan deteksi dan penanggulangan penyakit tersebut rendah akibat healthseeking behavior yang rendah sebagaimana ditunjukkan oleh penelitian Hassan (2017) di Nigeria.

Tabel 3. Sikap Subjek Mengenai TB

\begin{tabular}{|c|c|}
\hline Variabel & $\mathrm{N}(\%)$ \\
\hline \multicolumn{2}{|l|}{ Berat penyakit TB } \\
\hline Sangat tidak berat & $3(1,9)$ \\
\hline Tidak terlalu berat & $16(10,2)$ \\
\hline Sangat berat & $117(74,5)$ \\
\hline \multicolumn{2}{|l|}{ Reaksi bila terkena TB } \\
\hline Ketakutan & $76(48,4)$ \\
\hline Malu & $3(1,9)$ \\
\hline Sedih dan putus asa & $13(8,3)$ \\
\hline Terkejut & $46(29,3)$ \\
\hline \multicolumn{2}{|l|}{ Perlakuan terhadap pengidap TB } \\
\hline $\begin{array}{l}\text { Kebanyakan bersahabat, namun sebenarnya } \\
\text { mencoba menghindar }\end{array}$ & $31(19,7)$ \\
\hline Kebanyakan diasingkan & $11(7)$ \\
\hline Kebanyakan mendukung dan menolong & $85(54,1)$ \\
\hline
\end{tabular}

Tabel 4 memaparkan lebih lanjut lagi bagaimana perilaku subjek mengenai TB. Mayoritas subjek memilih berdiskusi dengan tenaga medis seperti dokter bila ingin mengetahui penyakit TB (50,3\%). Informasi yang didapatkan apabila seseorang tidak berdiskusi ke tenaga medis yang tepat dapat menyebabkan penyebaran informasi yang salah akan bahaya dan tata laksana penyakit TB. Kebanyakan subjek bersedia mendiskusikan penyakitnya bilamana terkena TB dan hanya 1 subjek $(0,6 \%)$ yang menyatakan tidak akan mendiskusikan penyakitnya bila terkena TB dikarenakan merasa malu. Terdapat kelompok pendukung (support group) yang membantu seseorang dengan penyakit kronis dapat membantu dalam tata laksana penderita. Dalam tata laksana TB, keberadaan keluarga atau orang dekat berperan penting sebagai Pengawas Minum Obat (PMO) untuk memastikan kepatuhan minum obat.

\section{Tabel 4. Perilaku Subjek Mengenai TB}

\begin{tabular}{ll}
\hline \multicolumn{1}{c}{ Variabel } & \multicolumn{1}{c}{$\mathrm{N}(\%)$} \\
\hline Orang yang akan diajak bicara bila terkena TB & \\
Dokter & $79(50,3)$ \\
Pasangan & $63(40,1)$ \\
Orangtua & $23(14,6)$ \\
Anak & $19(12,1)$ \\
Anggota keluarga lain & $26(16,6)$ \\
Teman dekat & $8(5,1)$ \\
Tidak seorangpun & $1(0,6)$ \\
Yang akan dilakukan bila terkena TB & \\
Mencari pengobatan sendiri & $4(2,5)$ \\
Pergi ke apotek & $3(1,9)$ \\
Pergi ke fasilitas kesehatan & $132(84,1)$ \\
Pergi ke pengobatan alternatif & $2(1,3)$ \\
\hline
\end{tabular}




\begin{tabular}{ll}
\hline Tahap pergi ke faskes & \\
$\begin{array}{l}\text { Ketika gejala yang dirasa seperti TB bertahan } 3-4 \\
\text { minggu }\end{array}$ & $21(13,4)$ \\
Ketika pengobatan sendiri tidak berhasil & $28(17,8)$ \\
Segera berobat ketika mengetahui terkena TB & $88(56,1)$ \\
Tidak akan pergi berobat & $3(1,9)$ \\
\hline
\end{tabular}

Mayoritas subjek akan pergi ke fasilitas kesehatan apabila terkena TB $(84,1 \%)$ namun masih ada subjek yang memilih untuk mencari pengobatan sendiri $(2,5 \%)$ ataupun berobat alternatif $(1,3 \%)$. Mayoritas subjek akan segera berobat ke fasilitas kesehatan bila terkena TB, namun masih ada subjek yang memilih tidak akan pergi berobat (1,9\%) dikarenakan berbagai alasan, seperti: biaya pengobatan yang mahal dan lokasi fasilitas kesehatan yang jauh. Penelitian yang dilakukan oleh Nataprawira (2014) permasalahan yang paling sering ditemukan dan menyebabkan keluarga tidak membawa pasien berobat TB, antara lain: masalah finansial, waktu, dan jarak fasilitas kesehatan yang jauh. Hal ini juga ditemukan dalam penelitian ini yaitu kesalahan dalam tata laksana TB dapat menyebabkan resistensi kuman TB terhadap obat antituberkulosis lini pertama. Strategi DOTS direkomendasikan $W H O$ dan International Standards for Tuberculosis Care (ISTC) untuk mengatasi masalah tersebut, namun masih banyak permasalahan di lapangan yang ditemukan.

Keterbatasan penelitian ini adalah bahwa penelitian ini merupakan bagian dari kegiatan Supercamp yang berlangsung dalam periode 1 hari saja sehingga tidak dapat mencakup banyak warga ataupun memantau perubahan sikap, dan perilaku setelah dilakukan intervensi sosialisasi media poster mengenai TB. Sikap, dan perilaku merupakan variabel yang sulit untuk dinilai hanya melalui satu kali pemeriksaan sehingga diperlukan intervensi dan pemantauan jangka panjang untuk dapat menilai perubahannya. Kelebihan penelitian ini adalah bahwa penelitian ini merupakan penelitian pertama yang dilakukan mengenai pengetahuan, sikap, dan perilaku masyarakat akan penyakit TB di daerah Pangandaran, Jawa Barat sehingga dapat menjadi pilot study untuk penelitian lebih lanjut.

\section{SIMPULAN}

Tingkat pengetahuan setelah dilakukan pemaparan menunjukkan hasil yang lebih baik dibanding dengan sebelumnya, akan tetapi masih terdapat kesalahan responden mengenai TB yang bahkan setelah dilakukan pemaparan masih kurang dimengerti masyarakat. Perubahan dalam pengetahuan, sikap, dan perilaku masyarakat akan TB dapat membantu mengurangi beban penyakit TB di dalam komunitas endemik TB.

\section{DAFTAR PUSTAKA}

DinihariTN,Dewi RK.(2013).Petunjuk teknis manajemen TB anak. Jakarta: Kementrian Kesehatan RI.
Hassan AO, et al. (2017). Knowledge about Tuberculosis: A precursor to effective TB control-findings from a follow-up national KAP study on tuberculosis among Nigerians. Tuberculosis Research and Treatment (8)1-8.

Hoelman B M, Parlinggoman BT, Eko S, Bahagijo S, Santono H. (2015). Panduan SDGs untuk Pemerintah Daerah (Kota dan Kabupaten) dan Pemangku Kepentingan Daerah. In: INFID, editor.

Nataprawira HM, Wonoputri N. (2014).

Obstacles facing tuberculosis treatment in children from a developing country: a hospital-based study. American Journal of Epidemiology and Infectious Disease. (2)8-12

Jain SK, et al. (2013). Pediatric Tuberculosis in young children in India: a prospective study. Biomed Research Int. 1-7.

Khan A, Walley J, Newell J, Indad N. (2000). Tuberculosis in Pakistan: sociocultural constraints and opportunities in treatment. Social Sci Med. (50)247-54.

Lertkanokkun S, Okanurak K, Kaewkungwal J, Meksawasdicha N. (2013). Healthcare providers' knowledge, attitudes \& practices regarding tuberculosis care. 1-10.

Noe A, Ribeiro RM, Anselmo R, et al. (2017). Knowledge, attitudes and practices regarding tuberculosis care among health workers in Southern Mozambique. Noé et al. BMC Pulmonary Medicine (2017) 17:2

Putera I, Pakasi TA, Karyadi E. (2015). Knowledge and perception of tuberculosis and the risk to become treatment default among newly diagnosed pulmonary tuberculosis patients treated in primary health care, East Nusa Tenggara: a retrospective study. BioMed Central. (238):1-6.

Raviglione M. (2015). Global Tuberculosis report. WHO. 20:1-204.

Salame FM, et al. (2017) Knowledge about tuberculosis transmission and prevention and perceptions of health service utilization among index cases and contacts in Brazil: Understanding losses in the latent tuberculosis cascade of care. PLoS ONE 12(9):e0184061

Seddon JA, Shingadia D. (2014). Epidemiology and disease burden of tuberculosis in children: a global perspective. Infect Dtug Resis. (7)153-65.

United States Agency International Development (USAIDS). (2013). The economic burden of tuberculosis in Indonesia. Management Sciences for Health. 